\title{
Synthesis and immunological evaluation of peptide-based vaccine candidates against malaria
}

\author{
Saranya Chandrudu', Mariusz Skwarczynski ${ }^{1}$, David Pattinson ${ }^{2}$, Simon H. Apte ${ }^{2}$, Denise L. Doolan ${ }^{2,3^{*}}$ and Istvan Toth ${ }^{1,4,5^{*}}$ \\ *Correspondence: i.toth@uq.edu.au and Denise.Doolan@qimr.edu.au

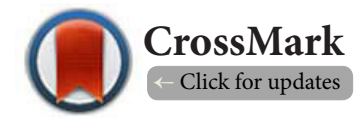

\begin{abstract}
'The University of Queensland, School of Chemistry and Molecular Biosciences, St Lucia QLD 4067, Australia. ${ }^{2}$ Infectious Diseases Programme, Queensland Institute of Medical Research, Herston, QLD 4006, Australia.

${ }^{3}$ The University of Queensland, School of Medicine, Herston, QLD 4006, Australia.

${ }^{4}$ The University of Queensland, School of Pharmacy, Woolloongabba, QLD 4102, Australia.

${ }^{5}$ The University of Queensland, Institute for Molecular Biosciences, St Lucia, QLD 4072, Australia.
\end{abstract}

\begin{abstract}
Background: Malaria, caused by the protozoan parasite Plasmodium, is one of the main causes of morbidity and mortality of the whole human population.Intensive, ongoing research aims to develop an effective vaccine against malaria; however, it has been unsuccessful for over a century. The circumsporozoite protein (CSP) plays crucial a role in the parasite life cycle. CSP is the most dominant surface antigen of the initial pre-erythrocytic stage. We designed vaccine constructs using four different $\mathrm{CD} 4^{+}$and $\mathrm{CD} 8^{+} \mathrm{T}$ cell epitopes derived from the CSP and used the lipid core peptide (LCP) as a self-adjuvanting delivery system.

Methods: All the constructs were synthesized using microwave-assisted solid phase peptide synthesis (SPPS). Immunological evaluation was carried out following subcutaneous administration of LCP-based vaccine candidates in a $\mathrm{BALB} / \mathrm{c}$ mouse model. Interferon gamma (IFN- $\gamma$ ) production was used to measure the induction of epitope-specific cellular immune responses after vaccination.

Results: Self-adjuvanting LCP malaria vaccines composed of different epitopes were synthesized.To determine whether the vaccine candidates were able to induce cellular immunity, mice were immunized with LCP constructs or peptide epitopes adjuvanted with cholera toxin.Two of the tested constructs induced a high level of INF- $\gamma$ in mice after subcutaneous immunization.

Conclusions: We have demonstrated here for the first time that the LCP delivery system induced epitopespecific cellular immune responses against an antigen derived from Plasmodium.
\end{abstract}

Keywords: Malaria, circumsporozoite protein (CSP), self-adjuvanting system, lipopeptide, peptide-based vaccine, cellular immune responses, $\mathrm{CD} 4^{+}$and/or $\mathrm{CD} 8^{+} \mathrm{T}$-cell epitopes, INF- $\gamma$ production

\section{Introduction}

Malaria is considered as one of the most prevalent diseases in developing countries. It causes about one million deaths annually and is a major health problem worldwide $[\mathbf{1}, \mathbf{2}]$. People living in areas where rainfall and temperature favour the growth of Plasmodium parasites are at the highest risk [3]. Four Plasmodium species, $P$. falciparum, $P$. vivax, $P$. malariae, $P$. knowlesi and $P$. ovale infect humans. Severe cases of malaria are mostly caused by $P$. falciparum and $P$. vivax, which are prevalent in sub-Saharan Africa and Southeast Asia, respectively [4-6]. The World Health Organization (WHO) launched the global malaria eradication programme in 1955 using chloroquine for the prevention and treatment of disease, and dichlorodiphenyltrichloroethane (DDT) for mosquito control [7]. The programme was abandoned in 1972 because of the emergence of Plasmodium parasites resistant to chloroquine and Anopheles mosquitoes resistant to DDT [8].

There are several drugs for the treatment of malaria nowadays; however, Plasmodium parasites are becoming resistant to majority of these medicines. In addition, the most effective treatments are often too expensive for many people in developing countries [9]. Despite intensive research is ongoing to develop an effective vaccine against malaria there is still no vaccine available on the market [10,11]. A complex life cycle and subsequent antigenic variations of the parasite are one of the major reasons for such a poor outcome [12]. 
There are three major approaches for the development of vaccines against malaria and they are related to the parasite life cycle stage. Vaccine candidates are developed to target the pre-erythrocytic stage(sporozoite), erythrocytic-stage(blood), or to block transmission of the parasite. Pre-erythrocytic stage vaccines aim to protect against initial infections of malaria by targeting the sporozoites in the liver. Blood-stage vaccines aim to reduce the morbidity and mortality of the disease and target parasites present in red blood cells. Transmissionblocking vaccines aim to block malaria transmission from mosquitoes to humans by preventing the malaria parasite from developing in the mosquito.

The circumsporozoite protein (CSP) is a major surface protein of the sporozoite (pre-erythrocytic) stage of malaria parasite and is the antigenic target of numerous vaccines against malaria, including RTS, S. RTS, S is a recombinant proteinbased vaccine containing the CSP-derived sequences; the NANP-repeating region; and the thrombospondin-like type I repeat (TSR) domain, which are attached to the $\mathrm{N}$-terminus of a hepatitis $B$ surface antigen [13]. At the end of an 18 month phase III clinical trial, GlaxoSmithKline (GSK) reported in October 2013 that this vaccine reduced the amount of malaria cases among infants by $25 \%$ and among young children by $50 \%$ [14]. RTS, $S$ is currently the most advanced vaccine against malaria and targets the pre-erythrocytic stage.

Peptide-based vaccines usually incorporate the minimal peptide epitope required to induce the preferred immune response. These vaccines were effective at stimulating both humoral and cellular immunity. Importantly, peptide-based vaccines can be designed to stimulate only the desired immune response and can even trigger protective immune responses more efficiently than whole protein-based approaches $[15,16]$. In addition, peptide-based vaccines can be produced easily in large-scale with high purity, freeze-dried, stored in solid form and customized for an appropriate immune response [17]. However, peptides by themselves are not immunogenic and to overcome this problem an adjuvant or appropriate delivery system is necessary $[1 \mathbf{1 8 , 1 9 ]}$.

Herein a self-adjuvanting lipopeptide vaccine delivery system also known as the lipid core peptide (LCP) was used to develop a malaria vaccine [20]. The LCP system consists of three major components: (a) a non-microbial lipid moiety (composed of two copies of synthetic lipoamino acid (e.g. 2-amino-D,L-hexadecanoic acid)), (b) a branching moiety, and (c) peptide epitopes [21]. The LCP system has been effective in delivering peptide-based vaccines against Chlamydia trachomatis [22], group A streptococcus [23], human hookworm infection [24] and Schistosoma [25]. We have designed a peptide vaccine based on the epitopes [26] derived from the CSP to induce immune responses that prevent malaria parasites entering into the bloodstream from the liver (Table 1). The vaccine constructs are comprised of the LCP delivery system and T-cell epitopes derived from the C-terminal fragment of the TSR domain. $\mathrm{ACD}^{+} \mathrm{T}$ cell immunodominant epitope on
Table 1. Lipid core peptide (LCP) constructs and sequence of incorporated epitopes. Overlapping region between epitopes $P 1$ and $P 2$ as well as P3 and P4 are marked in bold.

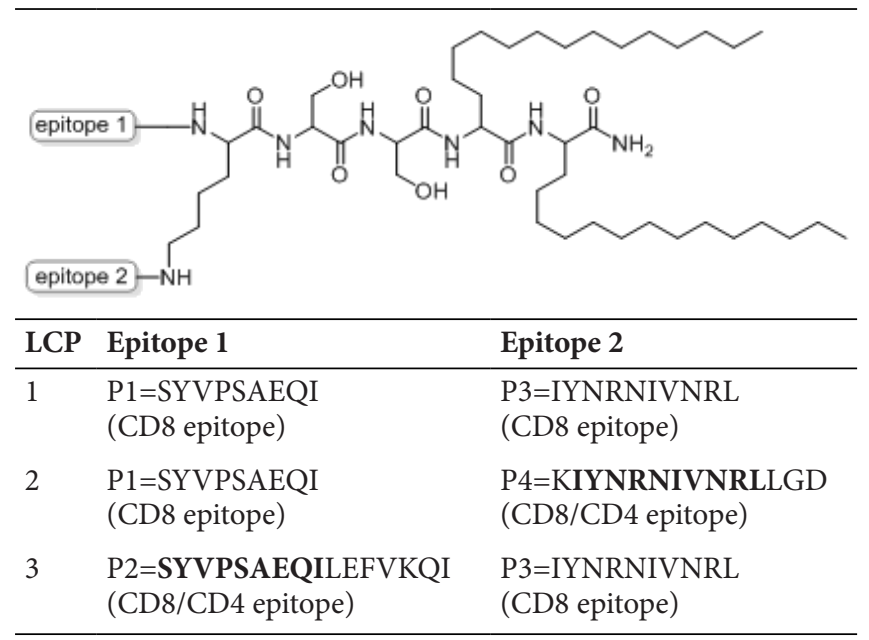

the sporozoite coat protein of $P$. yoelii (SYVPSAEQI) is nested within a dominant $C D 4^{+} T$ cell epitope (SYVPSAEQILEFVKQI) while $C D 8^{+} T$ cell epitopes (IYNRNIVNRL) is nested within a dominant CD4 ${ }^{+} \mathrm{T}$ cell (KIYNRNIVNRLLGD) [27]. Cellular immune responses induced against these epitopes were able to confer at least partial protection against sporozoite challenge $[\mathbf{2 8 , 2 9 ]}$. The immunogenicity of LCPs was evaluated based on the induction of epitope-specific cellular immune responses measured through the production of interferon gamma (INF- $\gamma)$.

\section{Materials and methods}

tert-Butoxycarbonyl (Boc) amino acids and $p$-methylbenzhydrylamine ( $p M B H A)$ resin were bought from Novabiochem (Switzerland). Trifluoroacetic acid (TFA), dichloromethane (DCM), $N, N^{\prime}$-dimethylformamide (DMF), $N, N^{\prime}$-diisopropylethylamine (DIPEA) and methanol were purchased from Merck (Hohenbrunn, Germany). 1-[Bis(dimethylamino) methylene]-1H-1,2,3-triazolo[4,5-b] pyridinium 3-oxid hexafluorophosphate(HATU) was obtained from Mimotopes (Clayton, VIC, Australia). HPLC grade acetonitrile was bought from Labscan (Bangkok, Thailand). All the other reagents were purchased at the highest available purity from Sigma-Aldrich (Castle Hill, NSW, Australia). Electrospray lonization-Mass Spectrometry (ESI-MS) was performed on a Perkin-ElmerSciex API3000 instrument with Analyst 1.4 software (Applied Biosystems/MDS Sciex, Toronto, Canada). Analytical Reverse Phase - High Performance Liquid Chromatography (RP-HPLC) was performed using an Agilent instrument with a $1 \mathrm{~mL} / \mathrm{min}$ flow rate and detection at $214 \mathrm{~nm}$. Separation was achieved using a $0-100 \%$ linear gradient of solvent $B$ over 40 min with $0.1 \% \mathrm{TFA} / \mathrm{H}_{2} \mathrm{O}$ as solvent $\mathrm{A}$ and $90 \% \mathrm{MeCN} / 0.1 \% \mathrm{TFA} / \mathrm{H}_{2} \mathrm{O}$ as solvent B on either a Vydac analytical C4 column (214TP54; 5 $\mathrm{mm}, 4.6 \mathrm{~mm} \times 250 \mathrm{~mm}$ ). Preparative RP-HPLC was performed on Shimadzu (Kyoto, Japan) instrument in linear gradient mode 
using a $10-20 \mathrm{~mL} / \mathrm{min}$ flow rate, with detection at $230 \mathrm{~nm}$. Separations were performed with solvent $A$ and solvent $B$ on a Vydac preparative C4 column (214TP1022; 10 mm, 22 mm×250 mm).

\section{Synthesis of lipopeptides}

LCPs were synthesized using microwave-assisted Boc chemistry by solid-phase peptide synthesis (SPPS) [30] at $20 \mathrm{~W}$ and $70^{\circ} \mathrm{C}$ similar to previous reports $[20,31]$. Briefly, the peptides were synthesized using $p M B H A r e s i n$. The amino acid was activated by combining it with HATU and DIPEA for two minutes before it was added to the resin with the exception of 2-amino-D,Lhexadecanoic acid which was activated five minutes prior to the coupling reaction. The resin was acetylated after the first amino acid was coupled. Coupling cycles consisted of $2 \times 10$ min cycles for each amino acid. The Boc-protecting group was removed by treatment with TFA at room temperature for $2 \times 1$ min. Resin was flow washed with DMF between couplings and deprotections. Once all the amino acids were attached, the resin was washed with DMF, DCM and methanol. After the synthesis was completed, the crude compound was cleaved from the resin using anhydrous HF. The product was then purified with preparative HPLC. C4 or C18 columns were used to analyse the samples in an analytical HPLC with a 0-100\% gradient of Solvent B over forty minutes.

\section{LCP 1}

HPLC analysis ( $C 4$ column): $t_{R}=31.81$ min, purity $>95 \%$. Yield: 11\%. ESI-MS: $[\mathrm{M}+2 \mathrm{H}]^{2+} \mathrm{m} / \mathrm{z} 1571.7$ (calc 1571.8), $[\mathrm{M}+3 \mathrm{H}]^{3+} \mathrm{m} / \mathrm{z}$ 1048.3 (calc 1048.2); MW $3141.79 \mathrm{~g} / \mathrm{mol}$.

\section{LCP 2}

HPLC analysis ( $C 4$ column): $\mathrm{t}_{\mathrm{R}}=30.54$ min, purity $>95 \%$. Yield: 12\%. ESI-MS: $[\mathrm{M}+2 \mathrm{H}]^{2+} \mathrm{m} / \mathrm{z} 1777.9$ (calc 1778.6), $[\mathrm{M}+3 \mathrm{H}]^{3+} \mathrm{m} / \mathrm{z}$ 1186.2 (calc 1186.1); MW $3555.26 \mathrm{~g} / \mathrm{mol}$.

\section{LCP 3}

HPLC analysis (C4 column): $t_{R}=30.80$ min, purity $>95 \%$. Yield: 10\%. ESI-MS: $[\mathrm{M}+2 \mathrm{H}]^{2+} \mathrm{m} / \mathrm{z} 2207.9$ (calc2207.6), $[\mathrm{M}+3 \mathrm{H}]^{3+} \mathrm{m} / \mathrm{z}$ 1471.9 (calc 1472.1 ); MW $4413.29 \mathrm{~g} / \mathrm{mol}$.

\section{Epitope P1}

HPLC analysis ( $C 18$ column): $t_{R}=30.80$ min, purity $>95 \%$. Yield: 10\%. ESI-MS: $[\mathrm{M}+2 \mathrm{H}]^{2+} \mathrm{m} / \mathrm{z} 1034.9$ (calc 1035.1), $[\mathrm{M}+3 \mathrm{H}]^{3+} \mathrm{m} / \mathrm{z}$ 518 (calc 518); MW $1034.12 \mathrm{~g} / \mathrm{mol}$.

\section{Epitope P2}

HPLC analysis (C18 column): $t_{R}=30.80$ min, purity $>95 \%$. Yield: 10\%. ESI-MS: $[\mathrm{M}+2 \mathrm{H}]^{2+} \mathrm{m} / \mathrm{z} 947.3$ (calc 947.1), $[\mathrm{M}+3 \mathrm{H}]^{3+} \mathrm{m} / \mathrm{z}$ 632.6 (calc 631.7); MW $1892.16 \mathrm{~g} / \mathrm{mol}$.

\section{Epitope P3}

HPLC analysis ( 18 column): $\mathrm{t}_{\mathrm{R}}=30.80$ min, purity $>95 \%$. Yield: 10\%. ESI-MS: $[\mathrm{M}+2 \mathrm{H}]^{2+} \mathrm{m} / \mathrm{z} 658.7$ (calc 658.8), $[\mathrm{M}+3 \mathrm{H}]^{3+} \mathrm{m} / \mathrm{z}$ 439.4 (calc 439.5); MW $1315.52 \mathrm{~g} / \mathrm{mol}$.

\section{Epitope P4}

HPLC analysis ( $\mathrm{C} 18$ column): $\mathrm{t}_{\mathrm{R}}=30.80$ min, purity $>95 \%$. Yield: 10\%. ESI-MS: $[\mathrm{M}+2 \mathrm{H}]^{2+} \mathrm{m} / \mathrm{z} 865.4$ (calc 865.5$),[\mathrm{M}+3 \mathrm{H}]^{3+} \mathrm{m} / \mathrm{z}$ 577.7 (calc 577.3 ); MW $1728.99 \mathrm{~g} / \mathrm{mol}$.

\section{Immunizations}

All the mice were immunized subcutaneously with $30 \mu \mathrm{g}$ LCPs in $50 \mu \mathrm{L}$ of phosphate buffered saline (PBS), $30 \mu \mathrm{g}$ of peptides formulated with powerful classical adjuvant $(\mathrm{P} 1+\mathrm{P} 3+$ cholera toxin (CT); P1+P4+CT; and P2+P3+CT) and PBS (negative control) followed by similar booster doses on days 21 and 42 post primary immunization. Specific pathogen-free female BALB/c mice (Animal Resources Centre, Perth, Australia, $n=5$ mice/group) were used at 5-6 weeks of age. The QIMR Animal Ethics Committee approved all animal studies and were conducted in accordance with the Australian Code of Practice for the Care and Use of Animals for Scientific Purposes (2004).

\section{ELISPOT assay}

Microplates (96-well) were initially pre-wet with $15 \mu \mathrm{L}$ of $35 \%$ ethanol and then washed with PBS. These plates were coated with $75 \mu \mathrm{L}$ of anti-mouse IFN- $\gamma$ capture antibodies, sealed and stored overnight at room temperature, then, the plates were flicked to remove any unattached anti-mouse IFN- $\gamma$ antibodies. Splenocytes were harvested from the mice and a single cell suspension was prepared as reported previously [32]. Full media along with $10 \%$ fetal calf serum (FCS) and $100 \mu \mathrm{L}$ of the purified cell suspension was added in each well $\left(5 \times 10^{5}\right.$ cells/ $\mathrm{ml}$ ). Each peptide pool or individual peptides were added to triplicate wells, and cultures were incubated for $48 \mathrm{~h}$ at $37^{\circ} \mathrm{C}$. The cell cultures were decanted and the wells were washed six times with PBS/Tween 20 using a plate washer. The plates were incubated for $60 \mathrm{~min}$ at $37^{\circ} \mathrm{C}$ in the presence of $75 \mu \mathrm{L}$ biotinylated anti-mouse IFN- $\gamma$ antibody in PBS, $0.5 \%$ of BSA and streptavidin. After the incubation time, the plates were thoroughly washed and $50 \mu \mathrm{L} /$ well of 3-amino-9-ethylcarbazole (AEC) substrate was added. When dark spots emerged, the plates were washed under tap water to end the reaction. IFN- $\gamma$ spot forming cells (SFCs) were counted using an ImmunoSpotElispot counter and the number of spots in the wells was used to calculate the number of SFCs per million spleen cells.

\section{Statistical analysis}

Statistical significance $(p<0.05)$ was determined using a oneway ANOVA with Bonferroni's post-hoc test (GraphPad Prism, San Diego, CA).

\section{Results and discussion}

Malaria remains a major cause of mortality reaching a million deaths per year. Insecticide resistance of mosquito and drug resistance of the parasite are one of the significant reasons explaining the current increase in mortality rate [33]. Therefore, there is strong need for effective vaccine against malaria.

Sporozoite stage of malaria is characterized by presence 
Chandrudu et al. Biochemical Compounds 2016,

of the parasites in the liver cells. Consequently, the vaccine developed against this stage should induce cellular immunity. Peptide-based vaccine candidates were designed to carry CD8 ${ }^{+}$and $C D 4^{+}$Tcell epitopes from CSP $[26,29,34,35]$ to induce a cellular response against the sporozoite (pre-erythrocytic) stage of malaria. These epitopes were synthesized by microwave assisted solid phase peptides synthesis (MW-SPPS) to produce: $\mathrm{CD} 8^{+} \mathrm{T}$-cell epitope P1 (SYVPSAEQI), CD8 ${ }^{+} / \mathrm{CD} 4^{+} \mathrm{T}$-cell epitope P2 (SYVPSAEQILEFVKQI), CD8 ${ }^{+}$T-cell epitope P3 (IYNRNIVNRL) and $\mathrm{CD}^{+} / \mathrm{CD} 4^{+}$T-cell epitope P4 (KIYNRNIVNRLLGD). The peptide epitopes were also incorporated into the LCP system using MW-SPPS. Two different epitopes were attached to each LCP using lysine as a branching moiety (Table 1).

To determine whether the vaccine candidates stimulated cellular immune responses, BALB/C mice were immunized subcutaneously with LCP1-3, peptides formulated with powerful classical adjuvant $(\mathrm{P} 1+\mathrm{P} 3+$ cholera toxin $(\mathrm{CT})$; $\mathrm{P} 1+\mathrm{P} 4+\mathrm{CT}$; and $\mathrm{P} 2+\mathrm{P} 3+\mathrm{CT}$ ) and PBS (negative control) followed by the same doses on days 21 and 42 post primary immunization.

In cellular immunity, activation of $\mathrm{CD} 4^{+}$and $\mathrm{CD} 8^{+} \mathrm{T}$ cells, are crucial to protect against the liver stage of malaria [36]. Previous research has indicated that inhibition of malaria parasite development in the liver was predominantly related to IFN- $\gamma$ production and CSP-specific $\mathrm{CD} 8^{+}$and $\mathrm{CD} 4^{+} \mathrm{T}$ cells were mainly responsible for its secretion [37]. Herein, following the immunizations, IFN- $\gamma$ producing cells from the spleens were analysed by ELISPOT. The spleen samples were restimulatedwith a mixture of the epitopes used for immunization (Figure 1). To further examine which LCP and epitope combination induced the strongest cellular response, epitope-specific production of IFN- $\gamma$ was also measured, by restimulating all the groups with individual peptides (in contrast to previous restimulation with whole peptide pool). Thus, LCP 1 and the control groups were restimulated with a mixture of $\mathrm{P} 1$ and $\mathrm{P} 3$ peptides (Figure 2a); LCP 2 with a mixture of

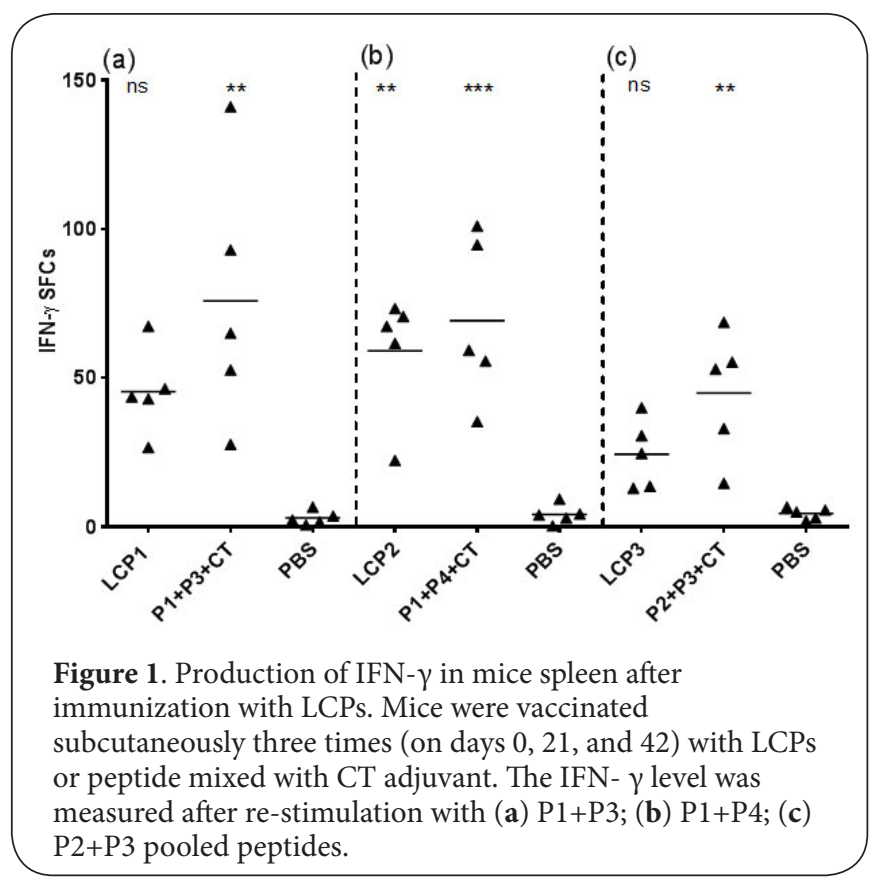

P1 and P4 peptides (Figure $\mathbf{2 b}$ ); and LCP 3 with a mixture of P2 and P3 peptides (Figure 2c). Once mice were immunized with peptide epitopes mixed with strong adjuvant (CT) all of them showed significant IFN- $\gamma$ production. All LCPs also stimulated high levels ofIFN- $\gamma$ production; of them LCP 2 showed a significant increase in this cytokine secretion. Although the CT adjuvant showed a high (expected) efficacy in stimulating a cellular response, it is not feasible to use this adjuvant in humans due to its toxicity [38]. To further examine which LCP and epitope combination induced the strongest cellular response, epitope-specific production of IFN- $\gamma$ was also measured, by re-stimulating all the groups with

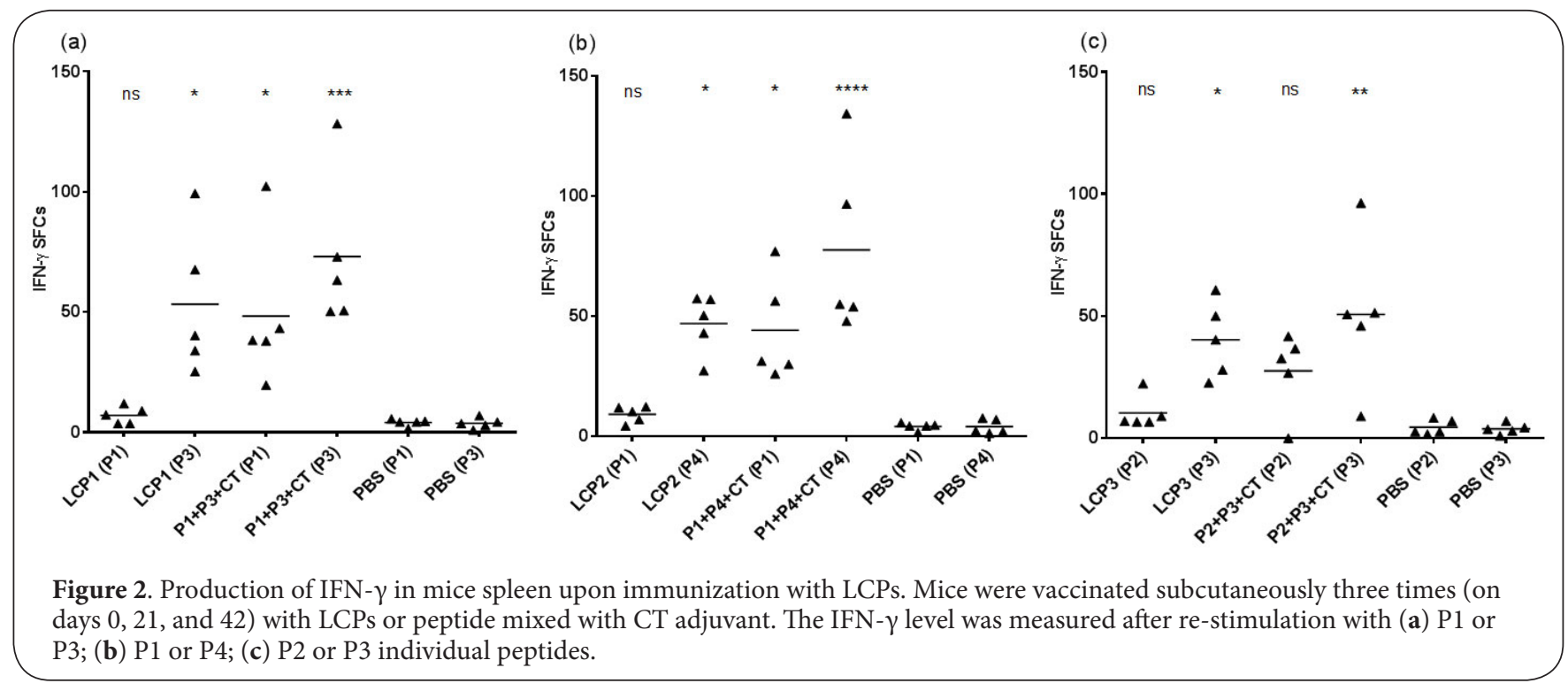


individual peptides. Interestingly, upon this re-stimulation, a high level of IFN- $\gamma$ production was detected in mice immunized with CT and epitopes P3 or P4 (Figure 2). P1 showed lower potency to stimulate cellular responses but still significantly higher than mice treated with PBS (Figures $\mathbf{2 a}$ and $\mathbf{2 b}$ ). A similar tendency was observed in mice immunized with LCP 1-3; significant responses were detected only for epitopes P3 and P4. Epitope P2, either incorporated in LCP construct or adjuvant formulations, did not induce any significant epitope-specific IFN- $\gamma$ production. Therefore, among the epitopes tested, P4 could be lead target for future vaccine development as P3 epitope sequence is incorporated inside the P4. P4 epitope also comprises of both $\mathrm{CD} 8^{+}$and $\mathrm{CD} 4^{+} \mathrm{T}$ cell epitopes and therefore should be able to induce long lasting immune responses [39].

We have successfully demonstrated that the LCP delivery system usually used for production of antibodies can also induce strong IFN- $\gamma$ production as a correlate of T cell activity. The cytokine production stimulated by the LCP constructs was not significantly lower than induced by classical adjuvant. The strength of response was clearly dependent on the choice of $\mathrm{CD}^{+} \mathrm{T}$ cell epitope. Two of the epitopes (P3 and P4) showed the ability of high IFN- $\gamma$ production upon immunization with the help of adjuvant as well as when incorporated into LCP. As P4 epitope overlaps P3 sequence, therefore in future studies, P4 is the most promising candidate for developing an antimalaria vaccine. The ability to induce a cell-mediated immune response after vaccination with a self-adjuvanting LCP system supports the ability of the system to be used as a platform for development of vaccines targeting intracellular pathogens.

\section{Competing interests}

The authors declare that they have no competing interests.

Authors' contributions

\begin{tabular}{|l|c|c|c|c|c|c|}
\hline Authors' contributions & SC & MS & DP & SHA & DLD & IT \\
\hline Research concept and design & -- & $\checkmark$ & -- & $\checkmark$ & $\checkmark$ & $\checkmark$ \\
\hline Collection and/or assembly of data & $\checkmark$ & -- & $\checkmark$ & -- & -- & -- \\
\hline Data analysis and interpretation & $\checkmark$ & $\checkmark$ & -- & -- & -- & -- \\
\hline Writing the article & $\checkmark$ & -- & -- & -- & -- & -- \\
\hline Critical revision of the article & -- & $\checkmark$ & -- & -- & -- & $\checkmark$ \\
\hline Final approval of article & $\checkmark$ & $\checkmark$ & $\checkmark$ & $\checkmark$ & $\checkmark$ & $\checkmark$ \\
\hline Statistical analysis & $\checkmark$ & -- & -- & -- & -- & -- \\
\hline
\end{tabular}

\section{Acknowledgement and funding}

This work was supported by the National Health and Medical Research Council of Australia (NHMRC 496600). We thank Thalia Guerin for her critical review of the manuscript.

Publication history

EIC: Mariusz Skwarczynski, The University of Queensland, Australia. Received: 10-Nov-2015 Final Revised: 15-Dec-2015

Accepted: 29-Dec-2015 Published: 12-Jan-2016

\section{References}

1. Matuschewski $\mathrm{K}$ and Mueller AK. Vaccines against malaria - an update. FEBS J. 2007; 274:4680-7. | Article | PubMed
2. Villard V, Agak GW, Frank G, Jafarshad A, Servis C, Nebie I, Sirima SB, Felger I, Arevalo-Herrera M, Herrera S, Heitz F, Backer V, Druilhe P, Kajava $A V$ and Corradin G. Rapid identification of malaria vaccine candidates based on alpha-helical coiled coil protein motif. PLoS One. 2007; 2:e645. | Article | PubMed Abstract | PubMed FullText

3. Hay SI, Omumbo JA, Craig MH and Snow RW. Earth observation, geographic information systems and Plasmodium falciparum malaria in sub-Saharan Africa. Adv Parasitol. 2000; 47:173-215. | PubMed Abstract I PubMed FullText

4. Singh B, Kim Sung L, Matusop A, Radhakrishnan A, Shamsul SS, CoxSingh J, Thomas A and Conway DJ. A large focus of naturally acquired Plasmodium knowlesi infections in human beings. Lancet. 2004; 363:1017-24. | Article | PubMed

5. Guerra CA, Gikandi PW, Tatem AJ, Noor AM, Smith DL, Hay SI and Snow RW. The limits and intensity of Plasmodium falciparum transmission: implications for malaria control and elimination worldwide. PLoS Med. 2008; 5:e38. | Article | PubMed Abstract | PubMed FullText

6. Gallup JL and Sachs JD. The economic burden of malaria. Am J Trop Med Hyg. 2001; 64:85-96. I PubMed

7. Najera JA, Gonzalez-Silva M and Alonso PL. Some lessons for the future from the Global Malaria Eradication Programme (1955-1969). PLoS Med. 2011; 8:e1000412. | Article | PubMed Abstract | PubMed FullText

8. van den Berg H. Global status of DDT and its alternatives for use in vector control to prevent disease. Environ Health Perspect. 2009; 117:1656-63. | Article | PubMed Abstract | PubMed FullText

9. Mabaso ML, Sharp B and Lengeler C. Historical review of malarial control in southern African with emphasis on the use of indoor residual house-spraying. Trop Med Int Health. 2004; 9:846-56. | Article I PubMed

10. Lorenz V, Karanis $G$ and Karanis P. Malaria vaccine development and how external forces shape it: an overview. Int J Environ Res Public Health. 2014; 11:6791-807. | Article | PubMed Abstract | PubMed FullText

11. Hoffman SL, Vekemans J, Richie TL and Duffy PE. The march toward malaria vaccines. Vaccine. 2015; 33 Suppl 4:D13-23. I Article I PubMed

12. Mackinnon MJ and Marsh K. The selection landscape of malaria parasites. Science. 2010; 328:866-71. I Article I PubMed

13. Coppi A, Natarajan R, Pradel G, Bennett BL, James ER, Roggero MA, Corradin G, Persson C, Tewari R and Sinnis P. The malaria circumsporozoite protein has two functional domains, each with distinct roles as sporozoites journey from mosquito to mammalian host. J Exp Med. 2011; 208:341-56. | Article I PubMed Abstract I PubMed FullText

14. Efficacy and safety of the RTS,S/AS01 malaria vaccine during 18 months after vaccination: a phase 3 randomized, controlled trial in children and young infants at 11 African sites. PLoS Med. 2014; 11:e1001685. | Article | PubMed Abstract | PubMed FullText

15. Rosalia RA, Quakkelaar ED, Redeker A, Khan S, Camps M, Drijfhout JW, Silva AL, Jiskoot W, van Hall T, van Veelen PA, Janssen G, Franken K, Cruz LJ, Tromp A, Oostendorp J, van der Burg SH, Ossendorp F and Melief CJ. Dendritic cells process synthetic long peptides better than whole protein, improving antigen presentation and T-cell activation. Eur J Immunol. 2013; 43:2554-65. | Article I PubMed

16. Pearson MS, Pickering DA, Tribolet L, Cooper L, Mulvenna J, Oliveira LM, Bethony JM, Hotez PJ and Loukas A. Neutralizing antibodies to the hookworm hemoglobinase Na-APR-1: implications for a multivalent vaccine against hookworm infection and schistosomiasis. J Infect Dis. 2010; 201:1561-9. | Article | PubMed

17. Skwarczynski $M$ and Toth I. Recent advances in peptide-based subunit nanovaccines. Nanomedicine (Lond). 2014; 9:2657-69. | Article | PubMed

18. Skwarczynski M., J. Kowapradit, Z.M. Ziora and I. Toth. pH-triggered peptide self-assembly into fibrils: a potential peptide-based subunit vaccine delivery platform. Biochemical Compounds. 2013. I Article

19. Skwarczynski M and Toth I. Peptide-based subunit nanovaccines. Curr Drug Deliv. 2011; 8:282-9. | Article | PubMed

20. Skwarczynski M and Toth I. Lipid-core-peptide system for selfadjuvanting synthetic vaccine delivery. Methods Mol Biol. 2011; 
Chandrudu et al. Biochemical Compounds 2016,

\section{1:297-308. | Article | PubMed}

21. Olive C, Batzloff M, Horvath A, Clair T, Yarwood P, Toth I and Good MF. Potential of lipid core peptide technology as a novel self-adjuvanting vaccine delivery system for multiple different synthetic peptide immunogens. Infect Immun. 2003; 71:2373-83. | Article | PubMed Abstract | PubMed FullText

22. Zhong G, Toth I, Reid R and Brunham RC. Immunogenicity evaluation of a lipidic amino acid-based synthetic peptide vaccine for Chlamydia trachomatis. J Immunol. 1993; 151:3728-36. | Article | PubMed

23. Zaman M, Chandrudu S, Giddam AK, Reiman J, Skwarczynski M, McPhun V, Moyle PM, Batzloff MR, Good MF and Toth I. Group A Streptococcal vaccine candidate: contribution of epitope to size, antigen presenting cell interaction and immunogenicity. Nanomedicine (Lond). 2014; 9:2613-24. | Article |

24. Fuaad AA, Pearson MS, Pickering DA, Becker L, Zhao G, Loukas AC, Skwarczynski M and Toth I. Lipopeptide Nanoparticles: Development of Vaccines against Hookworm Parasite. ChemMedChem. 2015; 10:164754. | Article | PubMed

25. Ahmad Fuaad AA, Roubille R, Pearson MS, Pickering DA, Loukas AC, Skwarczynski $M$ and Toth I. The use of a conformational cathepsin D-derived epitope for vaccine development against Schistosoma mansoni. Bioorg Med Chem. 2015; 23:1307-12. | Article | PubMed

26. Apte SH, Groves PL, Skwarczynski M, Fujita Y, Chang C, Toth I and Doolan $D L$. Vaccination with lipid core peptides fails to induce epitope-specific T cell responses but confers non-specific protective immunity in a malaria model. PLoS One. 2012; 7:e40928. | Article | PubMed Abstract | PubMed FullText

27. Apte SH, Groves PL, Skwarczynski M, Fujita Y, Chang C, Toth I and Doolan DL. Vaccination with lipid core peptides fails to induce epitope-specific T cell responses but confers non-specific protective immunity in a malaria model. PLoS One. 2012; 7:e40928. | Article | PubMed Abstract | PubMed FullText

28. Rodrigues MM, Cordey AS, Arreaza G, Corradin G, Romero P, Maryanski $\mathrm{JL}$, Nussenzweig RS and Zavala F. CD8+ cytolytic T cell clones derived against the Plasmodium yoelii circumsporozoite protein protect against malaria. Int Immunol. 1991; 3:579-85. | PubMed

29. Franke ED, Sette A, Sacci J, Jr., Southwood S, Corradin G and Hoffman SL. A subdominant CD8(+) cytotoxic T lymphocyte (CTL) epitope from the Plasmodium yoelii circumsporozoite protein induces CTLs that eliminate infected hepatocytes from culture. Infect Immun. 2000; 68:3403-11. | Article | PubMed Abstract | PubMed FullText

30. Chandrudu S, Simerska P and Toth I. Chemical methods for peptide and protein production. Molecules. 2013; 18:4373-88. | Article | PubMed

31. Liu TY, Hussein WM, Jia Z, Ziora ZM, McMillan NA, Monteiro MJ, Toth I and Skwarczynski M. Self-adjuvanting polymer-peptide conjugates as therapeutic vaccine candidates against cervical cancer. Biomacromolecules. 2013; 14:2798-806. | Article | PubMed

32. Cole GA. Interferon-gamma ELISPOT assay for the quantitative measurement of antigen-specific murine CD8+ T-cells. Methods $\mathrm{Mol}$ Biol. 2005; 302:191-204. | Article | PubMed

33. White NJ. Antimalarial drug resistance. J Clin Invest. 2004; 113:1084-92. | Article | PubMed Abstract | PubMed FullText

34. Weiss WR, Mellouk S, Houghten RA, Sedegah M, Kumar S, Good MF, Berzofsky JA, Miller LH and Hoffman SL. Cytotoxic T cells recognize a peptide from the circumsporozoite protein on malaria-infected hepatocytes. J Exp Med. 1990; 171:763-73. | Article | PubMed Abstract | PubMed FullText

35. Weiss WR, Houghten RA, Good MF, Berzofsky JA, Miller LH and Hoffman SL. A CTL epitope on the circumsporozoite protein of P. yoelii. Bull World Health Organ. 1990; 68 Suppl:99-103. | PubMed Abstract | PubMed FullText

36. Overstreet MG, Cockburn IA, Chen YC and Zavala F. Protective CD8 T cells against Plasmodium liver stages: immunobiology of an 'unnatural' immune response. Immunol Rev. 2008; 225:272-83. | Article | PubMed Abstract | PubMed FullText

37. Todryk SM and Walther M. Building better T-cell-inducing malaria vaccines. Immunology. 2005; 115:163-9. | Article | PubMed Abstract | PubMed FullText

38. Singh M and O'Hagan D. Advances in vaccine adjuvants. Nat Biotechnol. 1999; 17:1075-81. | Article | PubMed

39. Wahid R, Cannon MJ and Chow M. Virus-specific CD4+ and CD8+ cytotoxic T-cell responses and long-term T-cell memory in individuals vaccinated against polio. J Virol. 2005; 79:5988-95. | Article | PubMed Abstract | PubMed FullText

\section{Citation:}

Chandrudu S, Skwarczynski M, Pattinson D, Apte SH, Doolan DL and Toth I. Synthesis and immunological evaluation of peptide-based vaccine candidates against malaria. Bio Chem Comp. 2016; 4:1. http://dx.doi.org/10.7243/2052-9341-4-1 